\title{
Celebration of the 50th anniversary of publication of Histochemistry and Cell Biology
}

\author{
Jürgen Roth $\cdot$ H. Dariush Fahimi • Detlev Drenckhahn
}

Published online: 28 November 2007

(C) Springer-Verlag 2008

In 2008 we celebrate the 50th anniversary of Histochemistry and Cell Biology.

Histochemistry, defined as "structure related functional analysis of living matter" may appear at the first glance to be a young branch of biomedicine derived mainly from "classical histology". But careful reviews of the history of this field indicate that it dates back to the early part of the 19th century-in particular to the French botanist and microscopist Francois-Vincent Raspail (1794-1878; for a review see A.G.E. Pearse "Histochemistry, Theoretical and Applied", Vol. 1, 1980). It took almost a century and many devoted investigators until the principles of this scientific methodology, enabling functional analysis of cell and tissue structure by rendering molecules and molecular processes accessible to microscopic detection, became generally accepted.

The results and the observations of the first 100 years were summarized and published in 1930s by Lison in France (Histochimie Animale, 1936) and Romeis in Germany (Histochemische Methoden, 1932), paving the way for application of histochemical techniques in biology and medicine. A good decade later, there appeared then by now classical texts by Glick (Techniques of Histo- and

J. Roth

Department of Pathology, University of Zürich,

Schmelzberg str.12, 8091 Zürich, Switzerland

H. D. Fahimi $(\bowtie)$

INF 307, Heidelberg 69120, Germany

e-mail: H.Dariush.Fahimi@urz.uni-heidelberg.de

D. Drenckhahn

Institut for Anatomy and Cell Biology,

University of Würzburg, Würzburg, Germany
Cytochemistry, 1949), Gomori (Microscopic Histochemistry, 1952) and Pearse (Histochemistry, Theoretical and Applied, 1953). Nevertheless, in the early 1950s there were still no appropriate journals for publication of the many reports based on histochemical observations. This vacuum was rapidly realized and indeed within one decade, worldwide, numerous new journals were founded providing a forum for the publication of histochemical and cytochemical studies. To name just a few important examples with the dates of first appearance: Journal of Histochemistry and Cytochemistry (1953), Journal of Biophysical and Biochemical Cytology (which later changed to Journal of Cell Biology, 1955), Acta Histochemica (1954), Annales d'Histochimie (1956).

Exactly 50 years ago, in 1958, an international group of scientists founded the journal that later became Histochemistry and Cell Biology. The new journal initially carried the title "Abteilung Histochemie" (Histochemistry Division) of the "Zeitschrift für Zellforschung und mikroskopische Anatomie" and was first edited by M. Chèvremont, Liège; H.W. Deane, New York; P.B. Diezel, F. Duspiva and H. Reznik, Heidelberg; O. Eränkö, Helsinki; P. Gedigk and N. Schümmelfelder, Bonn; W. Gössner, Tübingen; W. Graumann, Göttingen; A.G.E. Pearse, London; W. Sandritter, Frankfurt/Main; T.H. Schiebler, Kiel; G. Siebert, Mainz; and M. Wolman, Tel-Hashomer. Retrospectively, the list of the international editors represented a list of who is who in histochemistry at that time.

Remarkable from the first issue on, as intended by the founders of The Journal, was the quality and quantity of the photographic reproductions, guaranteed by the printing press, the Universitätsdruckerei Stürtz in Würzburg, Germany. Besides high-quality black and white photomicrographs, superb color figures illustrated the results of the different techniques, and were invaluable for scientists who 
applied the published methods to validate their results. From the beginning, in German, English, French and Italian language written contributions reported advances in histochemical methodology, most with general applicability. Subsequently, both general technical reports and applications of novel histochemical methods to investigations of specific tissues, cells, or subcellular structures, were topics of the contributions. With volume 4 (1964/1965), The Journal became independent and was named "Histochemie/ Histochemistry/Histochimie". The internationality of the histochemical scientific community and of The Journal was reflected not only in that the title was trilingual but also in that the published articles were still written in different European languages. Accordingly, the authors came not only from different European countries, but also from the United States of America, and particularly from Japan. Thus, even this early in its existence, the journal enjoyed international recognition, and, presumably, had an impact on scientific communities around the world.

Since English became the predominant language in which the articles were published, with volume 38 (1974) the title of The Journal was changed to Histochemistry. Further eminent scientists from Europe, the United States of America and Japan joined the Editorial Board over time. In 1984, T.H. Schiebler, founding editorial board member of the journal and then head of the Anatomical Institute in Würzburg, Germany, became managing editor, first together with H.A. Padykula, Worcester, USA, and later, from 1987 on, sole managing editor. Board members in those years were R.R. Cowden, Johnson City, P. van Duijn, Leiden, O. Eränkö, Helsinki, P. Gedigk, Bonn, R. Gossrau, Berlin, W. Graumann, Tübingen, L.-I. Larsson, Copenhagen, Z. Lojda, Prague, B. Maurer-Schultze, Würzburg, A.E.F.H. Meijer, Amsterdam. K. Ogawa, Kyoto, W.K. Paull, Columbia, A.G.E. Pearse, London, D. Pette, Konstanz, M. van der Ploog, Leiden, H. Puchtler, Augusta, J. Roth, Basel, Y. Sano, Kyoto, L.A. Sternberger, Rochester, and W. Straus, North Chicago.

Throughout the years, the main objective of the journal's editors was the propagation of innovative advances and ingenious approaches in histochemical technologies, and their application to important questions in a wide variety of scientific fields ranging from embryology to neurobiology. This goal was reflected in numerous articles on, at the time, revolutionary new methods combining histochemistry and biochemistry or molecular biology, like immunocytochemistry for light and electron microscopy, in situ hybridization, or new live cell-imaging microscopical methods. Valued very highly by both authors and readers was the never wavering superior quality of the photographic reproductions, a benchmark which has been maintained over the years until today.
In 1992, Detlev Drenckhahn, Würzburg and Jürgen Roth, Zurich, became jointly Editors-in-Chief. They restructured the international Editorial Board, expanding the scope of the published manuscripts to take the many new perspectives of the modern cell biological research into account. This was followed in 1995 by a change in the title of The Journal to Histochemistry and Cell Biology to reflect the important role of cellular and molecular research in modern life sciences. Thus, over 50 years, the journal has maintained a consistent editorial policy of publishing new molecular methods and the results of application of those techniques to biological material, living cells and organisms, while remaining always open to novel ideas and hypothesis. Considering that the entire field of histochemistry is only about two hundred-years-old, 50 years is a considerable period of time and indeed The Journal during this time has matured into a highly reputed medium for reporting not only important observations in histochemistry and cytochemistry but also in modern cell biology and pathology using the most advanced tools and techniques.

One of the main objectives of Histochemistry and Cell Biology over the years has been the reporting of original research findings from the laboratory bench documenting the important role of cellular and molecular research in modern life sciences. But with the time as such primary information accumulates, the necessity arises to provide connecting bridges between the many disconnected facts of the original reports in order to give an overview of the essential principles of the function of cellular components. This task is best achieved by state-of-the-art reviews provided by experts in the field. On the occasion of its 50th anniversary, Histochemistry and Cell Biology intends to celebrate this event by publishing in the forthcoming issues of the year 2008 a series of review papers on important aspects of modern cell biology including the many state-ofthe-art technologies as practiced in expert laboratories. We have invited many well-known specialists from various fields of cell biology and pathology to summarize the presently available knowledge in their areas of expertise and we are very grateful that so many excellent scientists have consented to honour the 50th anniversary of the journal by preparing reviews of their respective fields covering major areas of modern cell and tissue biology.

The series of reviews start off with the present issue dealing with Cell Nucleus, followed by ER and Golgi Apparatus in February and Exocytosis and Endocytosis in March. In April Lysosomes, Autophagy and Peroxisomes are subjects of reviews and in May Cell Communication and Signalling Cascades are treated. The Cytoskeleton is reviewed in June and Cell Junctions in July. For the August issue reviews related to Functional Tissue Organization are planned. In September the state-of-the-art techniques in 
Pathology Research Laboratory, for October those in Neurobiology and for November the Advances of Imaging Techniques are reviewed. Finally, Cell Migration and Metastasis are the subjects of reviews for the December issue. We express our gratitude to the authors and hope that our readers enjoy and benefit from the forthcoming reviews.

Jürgen Roth, H. Dariush Fahimi and Detlev Drenckhahn 